\title{
NOTAS
}

\section{Religión y política en los Estados Unidos}

\section{Diego Alonso-Lasheras Zavala S.I.'}

Resumen: En este texto se aportan las claves históricas y contemporáneas que pueden ayudar a aclarar, desde una perspectiva española, la relación entre la religión y la política en los Estados Unidos (EEUU) con una doble intención: conocer mejor la política en los EEUU (cuyas decisiones se explican, en parte, teniendo en cuenta el fenómeno religioso en su manifestación estadounidense) y presentar un modelo de relación entre la esfera política y la esfera religiosa diferente del español.

Palabras clave: Religión, Política, Cultura, Historia, Estados Unidos.

Fecha de recepción: 22 de noviembre de 2010

Fecha de admisión definitiva: 20 de octubre de 2011

\section{Religion and politics in the U.S.A.}

Abstract: This paper provides historical and contemporary keys that can help clarify, from a Spanish perspective, the relationship between religion and politics in the United States, with two aims: one, to better understand U.S. policy (where decisions are explained, in part, taking into account American religious

\section{Religion et politique aux Etats-Unis}

Résumé: Ce texte apporte les clefs historiques et contemporaines qui peuvent nous aider à éclaircir, depuis une perspective espagnole, la relation entre la religion et la politique aux Etats-Unis, et tout cela avec une double intention: mieux connaître la

1 Profesor de Teología Moral. Universidad Gregoriana. Roma 
manifestations) and, second, to present a model of the relationship between the political and religious sphere in the U.S. and how it differs from what occurs in Spain.

Keywords: Religion; Politics; Culture, United States of America. politique aux Etats-Unis (dont les décisions s'expliquent, en partie, en tenant compte du phénomène religieux dans son expression aux Etats-Unis) et présenter un modèle de relation entre la sphère politique et la sphère religieuse, différent du modèle espagnol.

Mots clé: Religion, Politique, Culture, Histoire, Etats-Unis.

\section{Introducción}

Con periodicidad aparecen en los medios de comunicación españoles noticias que ponen de manifiesto la presencia de la religión en la vida política de los EEUU. Estas noticias tienden a generar desinformación porque, aunque relaten detalladamente ciertos hechos, no aportan al lector el marco de comprensión apropiado. El marco de la relación entre religión y política en Estados Unidos es radicalmente diferente al marco español y, por ello, la lectura que habitualmente se hace en los medios de comunicación de las noticias que llegan desde el coloso americano es una lectura distorsionada. ${ }^{2}$

Alexis de Tocqueville (1805-1859) en su libro La democracia en América decía ya en 1835 que en EEUU desde el principio, la política y la religión estuvieron de acuerdo, un acuerdo que aun no ha cesado ${ }^{3}$. Esta observación sigue siendo cierta hoy. Este artículo se propone aportar una serie de claves de lectura -históricas y contemporáneas- que permitan clarificar, desde una perspectiva española la relación entre la religión y la política en los Estados Unidos. Esto se hace con dos intenciones. Una intención es la de aportar claves para un mejor conocimiento de la política en los EEUU, actualmente el país más potente de la tierra. Si no se tiene en cuenta el fenómeno religioso en su manifestación estadounidense difícilmente se pueden comprender muchas de las decisiones de política interior y exterior-

\footnotetext{
${ }^{2}$ Toda la literatura periodística generada por la participación del Presidente del Gobierno, José Luís Rodríguez Zapatero en un desayuno de oración, el jueves 4 de febrero de 2010, no fue sino otro episodio de esta continuada "comedia de los errores".
}

${ }^{3}$ A. TOCQUeVILle (1848) p. 199 
aquellas que afectan más a los que somos ciudadanos de otros países-de la primera potencia mundial. El casi incondicional apoyo de los EEUU al estado de Israel o la constante disposición a participar en conflictos bien lejos de sus fronteras, son datos de la política norteamericana no interpretables si no se tiene en cuenta la clave religiosa.

Otra intención de este artículo es la de presentar un modelo de relación entre la esfera política y la esfera religiosa diferente del español. Me parece significativo presentar este modelo porque es el de un país desarrollado en el que religión y política se respetan mutuamente sin pensar la relación en términos de sumisión o de permanente conflicto. Aunque la realidad histórica y social española es bien diferente de la norteamericana, contemplar un modelo alternativo puede ser una ayuda para concebir una relación entre religión y política diferente de la difícil relación que hoy se vive en España.

El artículo se divide en dos partes: una primera presenta los principales hitos históricos que ayudan a explicar la relación entre la religión y la política; la otra se concentra sobre la realidad más reciente para intentar ofrecer unas claves de lectura adecuadas de la situación contemporánea.

\section{Los orígenes de una nación}

Una de las peculiaridades que distingue a los Estados Unidos del resto de los Estados del mundo occidental es el hecho de que nunca en su breve historia haya existido una religión oficial. Esto no sólo no es óbice para que se trate de un país extremadamente religioso, sino que más bien lo explica si tenemos en cuenta las raíces religiosas que conforman la identidad del país.

\section{I. Una nueva tierra de promisión}

Las trece colonias que, al independizarse del Reino Unido, dieron lugar a los Estados Unidos se fueron constituyendo, en parte, como lugares de refugio para aquellos que escapaban de persecuciones religiosas en Europa. Dos ejemplos claros de estos orígenes son el Estado de Massachussets y el Estado de Maryland. El ejemplo más famoso es el de Massachussets. A partir de los años 30 del siglo XVII, ante el rechazo y la persecución que sufrían en Inglaterra, los puritanos -una pequeña comunidad protestante inglesa de carácter rigorista y de tipo congregacionalista- 
comenzaron a emigrar a América. Empezaron a colonizar el territorio que hoy se conoce como Nueva Inglaterra. Los puritanos llegaron a Nueva Inglaterra en busca de libertad religiosa, aunque una vez asentados la libertad de culto que buscaban no la ofrecieron a los disidentes religiosos que surgieron entre ellos. La fundación de los estados de Conneticut y de Rhode Island tiene su origen en disidencias religiosas que llevaron a la expulsión de dichos disidentes, no sólo de la comunidad religiosa, sino también de la política. Otro ejemplo digno de tenerse en cuenta, $-y$ mucho menos conocido-es el de los orígenes del estado de Maryland que surge del sueño del segundo lord Baltimore de crear entre las colonias del Reino Unido una para los católicos ingleses. ${ }^{4}$

Se puede comprobar estudiando su historia que los orígenes más remotos del asentamiento de colonos europeos en el territorio de lo que llegará a constituir los EEUU está ligado en muchos casos a la búsqueda de libertad religiosa. Es decir que se produce en los colonos originales una mezcla de profunda religiosidad, ya que se ha estado dispuesto a soportar el exilio por mantener la propia fe, con una tendencia a creer en la libertad religiosa, porque se ha sufrido en carne propia las dificultades e injusticias de la persecución religiosa. La epopeya colonizadora de los EEUU será luego "cantada" -algo que da mucha más identidad al país que lo que rigurosamente ocurrió- como una búsqueda de libertad que incluye entre sus principales dimensiones la libertad de culto, motivo de la llegada de inmigrantes desde los primeros orígenes.

\subsection{Todos los hombres son creados iguales}

Cuando el 4 de julio de 1776 los representantes de las trece colonias reunidos en Filadelfia se emanciparon de la corona británica consideraron necesario enumerar las causas que les llevaban a esta Declaración de independencia. Los primeros párrafos fundan en la creación divina de la naturaleza humana su derecho a la independencia y sostienen que:

todos los hombres son creados iguales; que son dotados por su Creador de ciertos derechos inalienables; que entre estos están la vida, la libertad y la búsqueda de la felicidad; que para garantizar estos derechos se instituyen entre los hombres los gobiernos, que derivan sus poderes legítimos del consentimiento de los gobernados. ${ }^{5}$

${ }^{4}$ E. GAustad (1994).

${ }^{5} \mathrm{http}: / /$ www.archives.gov/exhibits/charters/declaration_transcript.html. La traducción es del autor. 
El acto fundacional de la república norteamericana cita en su párrafo inicial dos veces el nombre de Dios y usa el lenguaje teológico de la creación para justificar su nacimiento y los derechos inalienables de todos los hombres.

En 1789 la nueva nación se dotó de una constitución, una constitución extremadamente breve que no contiene una declaración de derechos. La Declaración de derechos de la Constitución americana, sin embargo, se encuentra en las 10 primeras enmiendas a la Constitución, propuestas por James Madison, inspirado por Thomas Jefferson, el redactor del borrador de la Declaración de independencia, y presentadas poco después de la aprobación de la Constitución. En esta Declaración de derechos, la primera enmienda se refiere a la libertad religiosa y dice que el Congreso no hará ninguna ley declarando oficial una religión o prohibiendo la libertad de culto. Junto a esta libertad de culto se declara la libertad de expresión, de prensa, de reunión y de dirigirse al gobierno para solicitar la reparación de las afrentas. ${ }^{6}$

La primera enmienda de la Constitución de la nueva nación establece que no habrá religión oficial, no con el fin de marginar la religión de la vida pública, ya que la declaración continúa diciendo que el estado no podrá prohibir el ejercicio de ninguna religión, sino con el fin de garantizar la libertad religiosa.

La primera enmienda no se puede entender como una exclusión de la religión. Ya en 1833, Joseph Story, uno de los primeros comentaristas de la Constitución americana consideraba que probablemente cuando se adoptó la Constitución y se hizo la enmienda ahora considerada el sentimiento general, sino universal en America era que el cristianismo debía ser fomentado por el estado, siempre que no fuera incompatible con los derechos privados de la conciencia y de la libertad de culto. Y continuaba afirmando que nadie hubiera aceptado una política que intentara igualar todas las religiones. Esto hubiera generado la desaprobación universal. El objeto de la primera enmienda no era pues prohibir el fomento del cristianismo, sino evitar la persecución religiosa y el establecimiento de una religión oficial de la nación. ${ }^{7}$

Es decir, que EEUU se constituye como país sin religión oficial pero un país creyente, o por lo menos deísta. Mientras en un país como España la Iglesia católica, por

${ }^{6} \mathrm{http}: / /$ www.archives.gov/exhibits/charters/bill_of_rights_transcript.html. Consultado el 24 de agosto de 2010.

7 J. StORY J., (1833), p.723, citado en ClOUd, M. W. (2004), p. 318. 
nuestra historia, es vista como institución rica y aliada durante siglos con el poder y esto provoca a veces en muchas personas un rechazo de la Iglesia Católica y a veces de la religión en general como algo alienante y opresivo, el pueblo americano piensa en la fe como una de las razones que movió a sus antepasados a emigrar, llegando a la nueva patria huyendo en muchos casos de la persecución religiosa. En EEUU, no sólo no se ve contradicción entre libertad e igualdad y fe religiosa vivida profundamente, sino que la visión que tienen es que una y otra se apoyan y necesitan y que parte de la grandeza de la nación reside en esa convivencia pacífica de credos.

\subsection{Manifest Destiny}

Como nación cristiana mayoritariamente protestante fruto de olas migratorias que en muchos casos han tenido como motivación la persecución religiosa, algo que impregna el imaginario colectivo de los norteamericanos es la idea de que EEUU es la nueva tierra de promisión. Un ejemplo de ello es el nombre de uno de los primerísimos asentamientos de los puritanos en Massachussets que llamaron Salem, uno de los nombres de Jerusalem en el Antiguo Testamento. Si la tierra de Caná fue para el pueblo de Israel la tierra de promisión que Dios les dio cuando los sacó de la esclavitud de Egipto, el territorio de los EEUU es una tierra de promisión para los oprimidos de la tierra y entre otros para los oprimidos por la persecución religiosa, como se sentían oprimidos los puritanos por el absolutista Carlos I Estuardo.

Si EEUU es la nueva tierra de promisión esto implica que ellos son el pueblo elegido por Dios. Aunque esto no se formula tal cual en ningún documento oficial, en el imaginario de los americanos existe la idea de que ellos son un pueblo elegido por Dios para extender la libertad y la igualdad. Esa idea de ser el pueblo elegido por Dios ya estaba presente en la conquista del oeste, otra de las epopeyas que configura la historia del país y el imaginario de todos. La conquista del oeste era una gesta para extender la libertad que se formula en la idea del "destino manifiesto".

En 1845 un político y editor del Morning Post de Nueva York, John O'Sullivan escribía: Es nuestro destino manifiesto el extendernos y tomar posesión de todo el continente que la Providencia nos ha dado para el desarrollo de este gran experimento de la libertad. La expresión "manifest destiny" - que se traduciría mejor como destino evidente- tuvo gran éxito y empezó a convertirse en moneda de uso común. Esta expresión fue la formulación conceptual de toda la conquista del oeste. 
Se trataba de una empresa bendecida por Dios, parte incluso del cumplimiento de los designios de la providencia divina. La empresa se articuló a través de la ley Homestead de 1841 que daba casi gratis 64 hectáreas de tierra a todo el que se estableciera en la tierra, la cultivara durante cinco años, construyera una casa y la habitara. ${ }^{8}$

En el plinto donde se levanta la Estatua de la Libertad están escritos los versos de la poetisa Emma Lazarus que dicen:

Dadme vuestras masas fatigadas, vuestros pobres, vuestras apiñadas masas que anhelan respirar libres,

los desdichados deshechos de vuestras rebosantes costas,

los que no tienen hogar, los zarandeados por la tempestad, imandádmelos!

Yo levanto mi lámpara junto a la puerta dorada. ${ }^{9}$

Estos versos resumen muy bien como los estadounidenses se ven a sí mismos: los descendientes de los marginados de otras naciones que han encontrado en una nueva tierra una nueva vida, mejor y más libre.

Como se ve tanto los orígenes y el desarrollo histórico del país hacen que la religión y en especial el cristianismo protestante estén muy presentes en la constitución política del país y en sus desarrollos legislativos. EEUU es una tierra de promisión, nación elegida por Dios, llamada a llevar a cumplimiento los planes de la providencia divina. Cuando en 1898 con motivo de lo que nosotros llamamos la guerra de Cuba, y ellos la guerra hispano-americana, EEUU dé el salto a la política internacional, estas ideas seguirán muy presentes.

Con esta misma idea participaron los EEUU en las dos guerras mundiales que eran en principio guerras europeas y a partir de la Segunda guerra mundial en la guerra fría. En ésta última se enfrentaban a la URSS que era a la vez una potencia atea y que negaba la libertad a su pueblo. Ateísmo y falta de libertad aparecen así unidos como enemigos a derrotar en el imaginario estadounidense. Es, si se presta atención, casi el estereotipo contrario al que reina en el imaginario europeo-hijo de la llustración francesa- que tiende a ver en la religión un factor de subyugación, no de liberación.

\footnotetext{
${ }^{8}$ F. MERK (1995) pp. 24-60.

${ }^{9}$ E. Lazarus (2002) pp. 19-20.
} 


\section{Religión y vida pública}

La religión es un elemento de la historia del pueblo americano muy presente en la vida pública y en la vida política que no es visto como un residuo histórico a superar. Robert Bellah considera que los grupos religiosos son un elemento importante de la idea de lo público en EEUU porque tienen algo positivo que aportar a la discusión sobre el bien público. La religión tiene algo esencial que decir a una ciudadanía responsable de una república democrática. Esto explica la existencia de una verdadera religión civil y la sobreabundancia del uso del nombre de Dios en el foro público.

\section{I. Las exigencias de la religión civil}

La sociología de la religión ha definido la religión civil americana como el sistema de símbolos religiosos que relacionan al ciudadano con el conjunto de la sociedad americana. Esta religión impregna las experiencias cotidianas de los estadounidenses ayudando a la integración social y legitima los "valores americanos". Esta religión civil es diferente de la comunidad política y de la comunidad religiosa, y $\sin$ embargo juega un papel en ambas y media en sus relaciones porque la religión civil americana cumple funciones religiosas que no realizan ni el estado ni la comunidad religiosa. ${ }^{10}$

Para Rober Bellah los "artículos de fe fundamentales" de esta religión son: la creencia en la existencia de Dios, la creencia que la nación americana está sometida a las leyes de Dios y el convencimiento de la protección y guía divinas de la nación. Entre los valores de la religión civil están la libertad, la justicia y la caridad. ${ }^{11}$

La religión civil americana estimula la pertenencia a una confesión religiosa y, en principio, no compite con ella. En EEUU se considera que a nadie se le debe imponer un credo concreto, pero es socialmente bien visto y de alguna manera revela que uno es un buen ciudadano el que pertenezca a una religión y viva comprometido con ella. Es decir que en la religión civil de EEUU es de alguna manera preceptivo ser religioso teológicamente hablando porque con ello uno revela que es una persona de principios, que comparte los valores socialmente aceptados, comprometida con la comunidad y activa en ella. En esto España es completamente

${ }^{10}$ G. GeHRING (1981) pp. 51-53.

${ }^{11}$ R. BELLAH (1974) pp. 26-27. 
diferente. En España una persona religiosa tiende a no mencionar su fe en el foro público y menos en el político. Mientras que en España puede ser peligroso para un político o para cualquier persona hablar de su fe en el desempeño de una función pública, porque de alguna manera podría ser descalificado por ello, en EEUU es más bien el ateo o el agnóstico el descalificado, si manifiesta su ateísmo o agnosticismo en el desempeño de una función pública. Lo políticamente correcto es ser religioso aunque no se deba forzar a nadie a una confesión concreta. Esto afecta a todo el mundo y de los políiticos se espera que sean buenos miembros de su confesión, que cumplan con ella y que así demuestren los buenos hábitos y la virtud que se espera que ejerciten en la vida pública.

\subsection{Sobreabundancia del uso del nombre de Dios}

Porque creer en Dios es "lo normal y evidente" y lo políticamente correcto, el nombre de Dios está presente en numerosas instancias de la vida pública y política. En la mayoría de las escuelas norteamericanas los estudiantes de primaria recitan al principio de la jornada el juramento de fidelidad a la bandera que dice: "Prometo lealtad a la bandera de los EEUU de América y a la República que representa: una nación bajo Dios, indivisible, con libertad y justicia para todos." El juramento a la bandera fue compuesto para ser recitado por un grupo de niños en la apertura de la Exposición mundial de Chicago de 1892 y adquirió rápidamente gran popularidad extendiéndose a muchas escuelas, aunque ninguna ley obligaba a ello. En 1954, en plena guerra fría, el Congreso añadió al juramento el "bajo Dios" que no se encontraba en el juramento de fidelidad original. ${ }^{12}$

También en época del presidente Dwight $D$. Eisenhower se aprobó una ley que establecía que la moneda de curso legal de los EEUU, las monedas y los billetes, llevaran la inscripción "Confiamos en Dios", que se convirtió a partir de este momento en el lema del país. Las sesiones del Tribunal Supremo, que en el sistema legal norteamericano cumple las veces del Tribunal Supremo y del Tribunal Constitucional en España, se inician con la proclamación: Dios salve a los EEUU y a su honorable tribunal ${ }^{13}$.

Si el presidente de los EEUU acaba normalmente sus discursos a la nación diciendo "Dios bendiga América" se debe en parte a la existencia de una canción que empieza

\footnotetext{
${ }^{12}$ M. W. Cloud (2004) pp. 323-324.

${ }^{13}$ lbid., pp. 326-33.
} 
así y que es oficiosamente el segundo himno nacional. Desde los acontecimientos del 11 de septiembre de 2001 en el descanso del séptimo tiempo del partido de baseball en el estadio de los Yankees de Nueva York se canta esta canción.

El nombre de Dios se invoca constantemente en la vida pública y política norteamericana, de una manera que en España cuesta entender. Aunque es verdad que hay manifestaciones contrarias a este uso tan difundido del nombre de Dios -a veces por parte de ateos y agnósticos, a veces por parte de personas religiosas que ven en ello un modo de idolatría-, la mayoría de los norteamericanos ve en ello algo normal que no contradice la separación de Iglesia y Estado y la libertad de culto. La percepción es que los ideales y compromisos de la religión civil americana han permitido el funcionamiento de los EEUU como una sociedad multirreligiosa y multiracial. ${ }^{14}$

\section{Religión y política en los últimos 30 años}

Desde la presidencia de Ronald Reagan la relación entre política y religión ha adquirido unas características particulares en las que puede resultar interesante detenerse para poder interpretar bien el actual modo de relación entre la religión y la política en EEUU.

\section{I. La irrupción de evangélicos y fundamentalistas}

Lo primero que hay que señalar como nuevo en el panorama político estadounidense a partir de la presidencia de Reagan es la aparición de los evangélicos y del verdadero fundamentalismo. Al decir fundamentalismo no me refiero a cualquier manifestación religiosa que aparece en la vida pública y que con ojos europeos es tachado con frecuencia de fundamentalismo, sino que me refiero a una rama del protestantismo que vive enfrentada con la modernidad y que ve en los métodos modernos de interpretación bíblica desarrollados por la teología liberal alemana del siglo XIX poco menos que una apostasía.

El fundamentalismo en sentido estricto nace en la Asamblea de Niágara de 1878 que declara lo que llama los cinco artículos fundamentales - de ahí el nombre de fundamentalismo-: la inspiración divina y la inerrancia de la Biblia, el nacimiento

${ }^{14}$ E. M. JOHNSON (2004) p. 229. 
virginal y la plena divinidad de Cristo, la muerte de Cristo entendida como sacrificio para satisfacer la justicia divina, la resurrección corporal de Cristo y el retorno corporal de Cristo el día del juicio final. No se puede dejar de señalar que estos artículos de fe son aceptados por cualquier católico medio sin que por ello se haga de él un fundamentalista, lo cual quiere decir que parte del fundamentalismo va más allá de los artículos de fe profesados y que éste tiene más que ver con una cierta manera de vivir la relación entre la fe y la sociedad. ${ }^{15}$

Este fundamentalismo que durante una buena parte del siglo XX se había mantenido más bien alejado de la escena pública, da un salto a la política poco antes de la elección de Ronald Reagan y contribuye en gran manera a su elección. Los orígenes del salto a la política hay que buscarlos en un grupo que se autodenomina "Moral Majority" formado por un pequeño grupo de pastores evangélicos que logra movilizar a más de 100.000 pastores y consigue que estos movilicen el voto.

\subsection{Moral Majority}

El movimiento "Moral Majority" reacciona contra el famoso caso "Roe contra Wade" en el que el Tribunal Supremo de los EEUU decretó que el aborto era un derecho de la mujer en los primeros tres meses del embarazo, derecho que los estados no podían limitar. Esta medida ciertamente superaba en su autorización y declaración del aborto como un derecho lo que era el consenso político norteamericano y el sentir general del pueblo norteamericano. Los efectos de esta sentencia se han hecho sentir en la política norteamericana desde entonces.

Junto a la batalla contra el aborto el movimiento "Moral Majority" se movilizó contra lo que veía como ataques a la familia tradicional: el movimiento feminista y el movimiento gay. Por último "Moral Majority" también reaccionaba frente al movimiento pacifista que se vio reforzado con la guerra del Vietnam y su abrupto final, la primera derrota militar de EEUU en su historia. "Moral Majority" abogaba por una fuerte política de defensa nacional que incluía el rearme frente a la URSS que era vista como poder rival y ateo. Otra razón para el rearme militar era el apoyo al Estado de Israel. ${ }^{16}$

${ }^{15}$ D. Alonso-Lasheras (2007) p. 286.

${ }^{16}$ L. P. Ribuffo (2006) pp. 42-49. 
La defensa del Estado de Israel por parte del fundamentalismo protestante se debe a que para algunos fundamentalistas la segunda venida de Jesucristo en gloria - uno de los fundamentales de la Asamblea de Niágara- pasa por la existencia del Estado de Israel. La segunda venida de Cristo en gloria no es un artículo de fe exclusivo de los fundamentalistas. Es uno de los artículos del credo nicenoconstantinopolitano que comparten católicos, protestantes y ortodoxos y que dice: "de nuevo vendrá con gloria para juzgar a vivos y muertos, y su reino no tendrá fin". Pero este artículo del credo cobra especial importancia por la manera de relacionarse religión y política en EEUU, y en especial para los fundamentalistas y los evangélicos, por la interpretación política que le dan al artículo. ${ }^{17}$

Con esta agenda (aborto, defensa de la familia tradicional y rearme militar) salta el fundamentalismo religioso protestante a la arena política en la época Reagan. Aunque nacido en ámbito protestante, hay católicos que simpatizan con el movimiento, fundamentalmente por la cuestión del aborto, y en menor medida como respuesta al movimiento feminista y al movimiento gay, y por lo mismo algunos rabinos, que añaden el tema del apoyo al Estado de Israel. "Moral Majority" irrumpió en la campaña de Reagan con esta agenda política y transformó lo que había sido el juego político hasta entonces.

"Moral Majority" no representaba una parte importante de la población norteamericana pero su caso ilustra muy bien cómo un movimiento religioso, aunque no represente grandísimos números puede ser muy influyente si se organiza bien. "Moral Majority" desarrolló una estrategia que le hizo tener un influjo que superaba con creces el de la gente que se podía identificar con el movimiento. Esto se explica por las particularidades del sistema electoral norteamericano.

El sistema electoral americano distribuye los miembros a elegir a la Cámara de Representantes, la cámara baja, en función del número de habitantes del Estado. ${ }^{18}$ Cada Estado a su vez se divide en circunscripciones electorales, y cada una de ellas elige uno de los miembros de la Cámara de Representantes que corresponde al Estado. Este sistema combinado con los bajos índices de participación electoral que se dan en Estados Unidos, hace que en muchos casos -y esto es especialmente verdad en los estados del centro del país con menor densidad de población y

\footnotetext{
17 Sobre la relación entre el cristianismo y el sionismo en los Estados Unidos, cfr. DAVIDSON L. (2005).

${ }^{18}$ La cámara alta, el Senado, está compuesta por 100 senadores, dos por Estado, independientemente de la población del estado. Esto hace que influir sobre la elección de un senador resulte mucho más difícil, sobre todo en estados muy poblados.
} 
mayor presencia de los evangélicos- la elección de un miembro de la Cámara de Representantes pueda ser cuestión de un número relativamente pequeño de votos. Un pastor evangélico no puede movilizar grandes cantidades de votos, pero una acción política sostenida desde el púlpito -o desde el tele-púltipo- sí que le puede hacer influir sobre algún millar de votos. Esto puede ser suficiente para la elección - la derrota de un candidato. Esta capacidad de movilizar el voto a nivel local, coordinada a nivel nacional, supuso un vuelco electoral. Este "poder de palanca" en la elección a la Cámara de Representantes y en el complicado sistema de elección indirecta del presidente a través de compromisarios llevó al poder al Partido Republicano con Ronald Reagan a la cabeza a principios de los años 80 .

\subsection{Reajustando la relación religión política}

El Partido Republicano tomó muy buena nota de la capacidad de movilizar el voto de "Moral Majority" en particular y de los pastores evangélicos en general. A partir de este momento los republicanos cultivaron su amistad y cercanía y, en una magistral campaña de "marketing" político, se posicionó como el partido de la gente religiosa (la mayoría de la población de los EEUU, como hemos visto) y el partido que defendía los valores morales. Hizo esto consiguiendo presentar ante la opinión pública al Partido Demócrata como un partido donde la fe no existía o resultaba irrelevante en campo político, un partido que no cultivaba valor moral alguno.

Uno de los éxitos de Bush fue el de saberse presentar como el candidato con valores morales. Además de los valores ya defendidos por "Moral Majority", Bush acuñó la expresión "conservadurismo compasivo" para contrarrestar la acusación de tener poca sensibilidad social. Una de las cosas que llevó a George Bush a la presidencia en su primera elección fue la idea de que quería mostrar la cara compasiva del conservadurismo. Esta frase tuvo mucho éxito sobre todo entre los votantes religiosos que por un lado se distancian de políticas sociales que pueden identificar con socialismo (calificativo que nadie quiere recibir en EEUU), y al mismo tiempo parece tener en cuenta la cuestión de la preocupación por los más pobres y desfavorecidos que es un tema inevitable de la fe cristiana y que está presente en la mente de los estadounidenses. Porque la idea de pueblo elegido y destino manifiesto tiene como cara negativa el imperialismo pero como cara positiva una generosidad y un compromiso con la comunidad, grande por parte del norteamericano medio. ${ }^{19}$

${ }^{19}$ L. P. Ribuffo (2006) pp. 42-49. 
Mucha gente, incluso aquellos que no eran votantes natos de Bush le votaron. El ejemplo más claro es el voto católico. Hay dos razones que explican la tradicional identificación del voto católico en EEUU con el Partido Demócrata. La mayoría de los católicos norteamericanos proceden de una inmigración más bien reciente, lo que suele equivaler a estratos más bajos de la escala socio-económica. Una parte importante de los católicos norteamericanos son, o al menos han sido hasta hace poco, de clase obrera y por lo tanto más tendentes a identificarse y votar a un partido a la izquierda del espectro político ${ }^{20}$, que se presenta como defensor de las clases más populares frente a los intereses de aquellos de posición socio-económica elevada. La segunda razón de la identificación tradicional del voto católico con el Partido Demócrata se debe a que las élites sociales tradicionales de los EEUU, votantes en su mayoría del Partido Republicano, han tendido a identificarse con la etiqueta WASP (White Anglo Saxon Propestant): blanco, anglosajón y protestante. Los católicos evidentemente no son protestantes, pero además de esto en su mayoría tampoco anglosajones. Los católicos norteamericanos proceden en su mayoría de diversas olas de inmigración alemana, irlandesa, polaca, italiana y, más recientemente, latino americana. Los latinoamericanos, una fuerza creciente en el catolicismo estadounidense, independientemente de su verdadero origen entran en la clasificación Hispanic, por definición diferente de la raza blanca.

Presentándose como hombre que respaldaba los valores morales George W. Bush fue el primer presidente republicano de la historia de los EEUU en recibir la mayoría del voto católico. ${ }^{21}$

Los demócratas por el contrario cometieron un error táctico. Como reacción a la irrupción de "Moral Majority" y de los pastores evangélicos en la política tendieron a evitar las cuestiones religiosas como si fueran tabú, como si religión en política equivaliese a fundamentalismo y por lo tanto fuese mejor evitarlo. Fue un grave error, porque al dejar el tema de lado fomentaron que las personas religiosas les vieran como ateos, lo cual no era verdad, y un partido sin verdaderos valores morales, lo que tampoco era verdad; pero al ser percibidos así y no contrarrestar esta percepción errónea se alienaron una parte importante de los votantes.

\footnotetext{
${ }^{20}$ Hay que advertir que muchas posiciones políticas en cuestiones sociales mantenidas por el Partido Demócrata en EEUU serían de común aceptación por parte del conservadurismo europeo. El caso de la cobertura sanitaria para toda la población es el ejemplo más evidente y más reciente que pone de manifiesto la dificultad de identificar posiciones de izquierda y de derecha de EEUU y de Europa.

${ }^{21}$ Pew Reserch Center (2004).
} 


\subsection{La última elección presidencial y la presidencia de Obama}

En las elecciones presidenciales de 2004 que dieron a George W. Bush la presidencia por segunda vez, Jim Walis, pastor evangélico y profesor de Harvard de tendencias demócratas, advertía sobre el problema de los demócratas con la religión. Los candidatos demócratas evitaban entrar en "temas religiosos", al hacer esto no sólo se alienaban muchos posibles votantes sino que además dejaban que fueran los republicanos los que definieran en qué consistían estos temas religiosos. Los republicanos solían reducir estos temas al aborto, las cuestiones del movimiento gay y un cierto uso del nombre de Dios en las vida pública. Los candidatos demócratas seguían esta táctica declarándose creyentes pero afirmando que apoyaban la separación Iglesia-Estado y que no dejarían que su fe influyera en sus decisiones políticas. Al hacer estos no sólo cometían un error táctico político, sino que como Wallis advertía descuidaban una parte importante de la tradición político-religiosa de la nación. La lucha por la abolición de la esclavitud o a favor del sufragio de la mujer surgieron y eran expresión de profundas convicciones religiosas. Wallis se interrogaba retóricamente sobre qué hubiera sido de la lucha por los derechos civiles a final de los 50 y principios de los 60 , si personas como el reverendo Martin Luther King Jr. hubiera dejado que su fe fuera algo privado que no debía mezclarse con la política. ${ }^{22}$

El Partido Demócrata aprendió la lección y en las elecciones presidenciales de 2008 hizo de la religión y de la fe de sus candidatos una cuestión principal, hasta el punto que algunos analistas consideran que en estas elecciones la cuestión de la presencia de la religión en la vida pública América ha sido debatida como pocas veces. ${ }^{23}$

En junio de 2007 los tres principales candidatos demócratas (Edwards, Clinton y Obama) participaron en un debate televisivo organizado por Sojourners -grupo al que pertenece Jim Wallis-, para hablar de cómo la fe afecta su vida, incluso su vida política. ${ }^{24}$ En su campaña electoral, una vez elegido candidato del Partido Demócrata, Barak Obama no ha dudado en mostrarse en público como hombre de fe, si bien esto en ocasiones le ha costado caro, sobre todo cuando Jeremiah Wright pastor de su iglesia realizó una serie de explosivas afirmaciones pidiendo

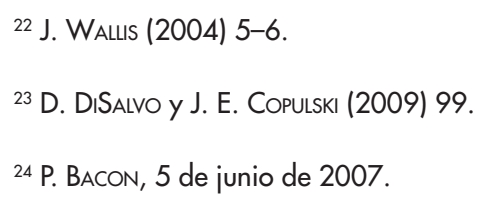


que Dios condenara América por sus pecados. ${ }^{25}$ Después de estas declaraciones Obama tomó sus distancias de él .

Hay que advertir, sin embargo, que al entrar de lleno en la cuestión de la relación entre religión y política Obama no ha aceptado el modelo que podríamos llamar evangélico-republicano de los treinta años anteriores. La posición de Obama se inspira fundamentalmente en la filosofía política de John Rawls. Este famoso filósofo afirma que la religión conduce a certezas y la democracia a la apertura, lo que implica que en un régimen político democrático sólo son aceptables propuestas políticas que se fundamenten en argumentos de carácter racional. Una propuesta política, aunque tenga una motivación e impulso religioso, sólo puede ser legítimamente formulada en un lenguaje secular. ${ }^{26}$ Obama sostuvo a largo de su campaña que presentar propuestas políticas ofreciendo como argumento principal una doctrina eclesial o la voluntad de Dios no es aceptable y afirmaba la necesidad de una "traducción" de estas propuestas y de su fundamento en un lenguaje que todos puedan comprender. ${ }^{27}$ Para Obama la política en una democracia exige la persuasión y para conseguirla es necesario un lenguaje común. ${ }^{28}$

La otra cuestión importante en la relación política y religión que Obama afrontó es la del peso histórico del cristianismo en EEUU, algo que se ha señalado en la primera parte de este artículo, y afirmó que EEUU no puede concebirse como nación cristiana, sino que la política del país debe tener también en cuenta a judíos, musulmanes, budistas o no creyentes. ${ }^{29}$ Una propuesta de este tipo se puede considerar oportunismo electoral o puede responder a una profunda convicción pero en todo caso encaja perfectamente con la historia personal de Barak Obama, hijo de un inmigrante de Kenia, nacido en Hawai y que ha vivido ocho años de su vida en Indonesia, país mayoritariamente musulmán pero con minorías de cristianos, hindúes y budistas.

\footnotetext{
${ }^{25}$ Estos pecados incluían la política imperialista del país y la sorprendente afirmación de que el gobierno de los EEUU había introducido el virus del SIDA en la comunidad negra. Cfr. D. DISALvo y J. E. CopULSKI (2009) 103.

${ }^{26} \mathrm{~A}$ la propuesta de Rawls se puede contrargumentar con razón que parte de una petición de principio pues da una definición de lo que es la razón y lo racional que asume como postulado que el lenguaje religioso es necesariamente irracional, afirmación cuando menos cuestionable.

${ }^{27}$ Algo que sorprendentemente recuerda la noción de ley natural de la tradición católica.

${ }^{28} \mathrm{Ibid}$. (2009) p. 102.

$29 \mathrm{lbid}, 101-102$.
} 
Los resultados de las elecciones presidenciales parecen haber premiado la propuesta de Obama. Las minorías religiosas votaron por él. Obtuvo la gran mayoría del voto negro y el voto católico de los hispanos, a pesar de que en estos dos grupos la oposición al aborto y a los "derechos de los gays" es fuerte, mientras que la postura de Obama no es de oposición. Obama no convenció a la mayoría de los católicos blancos, pero sí a la mayoría de los católicos. También conquistó la mayoría de los votos de los protestantes de las iglesias tradicionales y consiguió con los protestantes evangélicos mejores resultados de los conseguidos por sus antecesores. ${ }^{30}$ Se podría concluir que Obama fue capaz de convencer a una parte importante del voto religioso. Los únicos que no votaron mayoritariamente por él fueron los evangélicos lo cual era de esperar. A esto hay que añadir que las minorías religiosas que votaron por Obama están creciendo y es de suponer que representarán en el futuro una parte mayor de la sociedad norteamericana. Esto puede jugar a favor de los demócratas si Obama consigue mantener su fidelidad.

La religión y la política están destinadas a tener una relación siempre cambiante en los EEUU. La aprobación de la ley para extender la cobertura médica a un mayor número de ciudadanos ha sido la ocasión de uno de los últimos encuentros y desencuentros entre política y religión. Por un lado la extensión de la cobertura médica a toda la población o a la mayor parte de la población es algo deseado por quienes desde la fe cristiana sienten las exigencias de la justicia, por otro lado estas mismas personas han visto en la ley propuesta por Obama un riesgo de que se destinasen fondos federales a la práctica del aborto. Esto causó una disidencia en las filas del Partido Demócrata liderada por el católico Bart Stupak, que sólo votó a favor de la ley una vez que le fue asegurado que no se destinarían fondos federales a financiar el aborto. ${ }^{31}$

Otra importante novedad es la irrupción del Islam en la escena política norteamericana. Los trágicos hechos del 11 de septiembre de 2001 han contribuido a problematizar la reciente presencia del Islam en la vida pública de los EEUU. Más recientemente la crisis provocada por el proyecto de construcción de un centro islámico en la "Zona Cero" -y el apoyo del Presidente Obama a esta iniciativa-ponen a prueba la noción y la práctica de la libertad religiosa. La tradicional libertad religiosa concebida fundamentalmente como convivencia pacífica y harmónica

\footnotetext{
30 J. C. GREen (2009) 42-48.

${ }^{31}$ Para comprender la complicación de la cuestión es interesante leer la justificación de su voto dada por Bart Stupak en su página web oficial: http://www.house.gov/stupak/issues_healthcare_update. shtml, consultada el 20 de mayo de 2010.
} 
entre cristianos, empieza a experimentar sus límites con la irrupción del Islam, especialmente después del 11 de septiembre. Probablemente en este sentido estamos asistiendo a un cambio de modelo que va de un cierto ecumenismo cristiano a un verdadero pluralismo religioso.

\section{Conclusión}

Las claves hasta ahora presentadas no pretenden agotar la cuestión de la relación entre religión y política en EEUU, sino más bien las características principales de esta relación en el coloso norteamericano para hacerlo inteligible a un público español que, por razones fundamentalmente de carácter histórico, concibe esta relación de otra manera y con frecuencia puede hacer una lectura errónea de los fenómenos de los que se nos informa desde el otro lado del Atlántico.

La diferencia histórica y cultural que nos separa de los Estados Unidos hace difícil, y tampoco sé si sería deseable, la importación del modelo norteamericano. Sin embargo creo que la comparación puede ayudar en algún sentido a iluminar la situación española. Frente a quien lo juzga imposible, la realidad de los EEUU demuestra que es posible la presencia pública de la religión en una sociedad moderna y pluralista, sin imposiciones por parte de la religión y sin que el Estado coarte la libertad religiosa. Es posible presentar la sabiduría de la tradición cristiana en la vida pública no como imposición de la fe sino como contribución de un cuerpo social al bien de toda la sociedad. ${ }^{32}$ Como ejemplo reciente de esto, la Iglesia española puede reclamar sin complejos el papel clave de apoyo a la consolidación de la democracia que jugó durante la Transición, ya que la separación Iglesia-Estado no fue algo casual sino guiada por una generación de obispos. Esta separación dio más libertad a la Iglesia y a la vez contribuyó a la consolidación del Estado democrático.

La religión está llamada a jugar un papel en la vida pública sin por ello lesionar el derecho a la libertad religiosa y el principio de la separación Iglesia-Estado.

Si hubiera que calificar de algún modo la relación entre religión y política en los EEUU probablemente el adjetivo más adecuado sería "vital". Vital porque es una relación viva y por ello cambiante, a veces fructífera y en otras ocasiones conflictiva, esto es lo que hace de ello un fenómeno interesante, y no solo interesante, sino instructivo.

${ }^{32}$ M. J. HiMES Y K. R. HIMES (1993) 4. 


\section{Bibliografía}

Alonso-LASHeRAs, D. (2008) "Fundamentalismo religioso y política en Estados Unidos": Razón y Fe (256), 283-292.

Bacon, P. (2007) "Clinton, Edwards and Obama Discuss their Faith at Forum: Washington Post, 5 de junio de 2007 (consultado el 25 de agosto de 2010).

BellAH, R., (1974) "Civil Religion in America”, in RICHEY, R. B. y Jones, D. G., editores, American Civil Religion, Nueva York, Harpers and Row, pp. 24-41.

Cloud, M. W., (2004), "One Nation Under God: Tolerable Aknowledgement of Religion or Unconstitutional Cold War Propaganda Cloaked in American Civil Religion?": Journal of Church and State, 45, 311-340.

DaVIDSON, L., (2005) "Christian Zionism as a Representation of American Manifest Destiny": Critique: Critical Middle Eastern Studies (14), 157-169.

GAUSTAD, E., (1994) "Quest for pure Christianity": Christian History [serial online] 13 (1): 8. Disponible en Academic Search Complete, Ipswich, MA (consultado el 22 de abril de 2010).

GeHRING, G., (1981) "The American Civil Religion Debate: A Source for Theory Construction": Journal for the Scientific Study of Religion 20 (1), 51-63.

GreEN, J. C., (2009) "What Happened to the Values voter? Believers and the 2008 election": First Things, 3, 42-49.

Himes, M. J. y Himes, K. R., (1993) Fullness of Faith: The Public Significance of Theology, Nueva York, Paulist.

JoHnson, S. M. (2004) "American Civil Tradition alter 9/11: Protestant, Catholic, Jewish, and African-American Resources for Healthier National Faith and Community": Implicit Religion, 7 (3) 228-245.

LAZARUS, E., Selected Poems and Other Writings, Peterborough, Broadview.

Merk, F., Manifest Destiny and Mission in American History, Cambridge (MA), Harvard University. 
Pew Research Center (6 de diciembre de 2004) "Religion and the Presidential Election. Bush Gains Broad-Based" (consultado el 24 de agosto de 2010).

RibufFo, L.P. (2006) "George Bush and the Latest Evangelical Menace": Dissent 4, $42-49$.

DE TocquevilLe, A. (1848) De la démocratie en Amérique, Paris.

Wams, J. (2004) "The Democrats Religious Problem": Sojourns 2, 5-6. 